\title{
EXPERIMENTAL AND NUMERICAL STUDY OF A VENTURI TUBE AS A DIDACTIC TOOL FOR CHEMICAL ENGINEERING LEARNING
}

\section{MEDIÇÃO DE VAZÃO ATRAVÉS DE UM TUBO DE VENTURI - ESTUDO EXPERIMENTAL E NUMÉRICO COMO FERRAMENTA PARA A APRENDIZAGEM DE ENGENHARIA QUÍMICA}

\author{
F. O. $\operatorname{COSTA}^{1,{ }^{*},}$ J. T. MARTINS${ }^{2}$, C. G. S. FERREIRA ${ }^{3}$, G. K. T. ANDRADE ${ }^{4}$, F. L. B. MATEUS ${ }^{5}$ e R. A. B. LIMA- \\ CORRÊA $^{6}$
}

${ }^{1}$ Universidade Federal de Lavras, Departamento de Engenharia, Lavras, Minas Gerais, Brasil ORCID: https://orcid.org/0000-0002-1973-8350

${ }^{2}$ Universidade Federal de Lavras, Departamento de Engenharia, Lavras, Minas Gerais, Brasil ORCID: https://orcid.org/0000-0003-3672-6826

${ }^{3}$ Universidade Federal de Lavras, Departamento de Engenharia, Lavras, Minas Gerais, Brasil ORCID: https://orcid.org/0000-0003-0754-9082

${ }^{4}$ Universidade Federal de Lavras, Departamento de Engenharia, Lavras, Minas Gerais, Brasil ORCID: https://orcid.org/0000-0003-3101-9751

${ }^{5}$ Universidade Federal de Lavras, Departamento de Engenharia, Lavras, Minas Gerais, Brasil ORCID: https://orcid.org/0000-0002-6015-4795

${ }^{6}$ Universidade Federal de Lavras, Departamento de Engenharia, Lavras, Minas Gerais, Brasil ORCID: https://orcid.org/0000-0001-5486-6879

*Universidade Federal de Lavras, Departamento de Engenharia Química, Lavras, Minas Gerais, Brasil, Telefone: +55 35998310839

Endereço de e-mail: felipe.costa@estudante.ufla.br

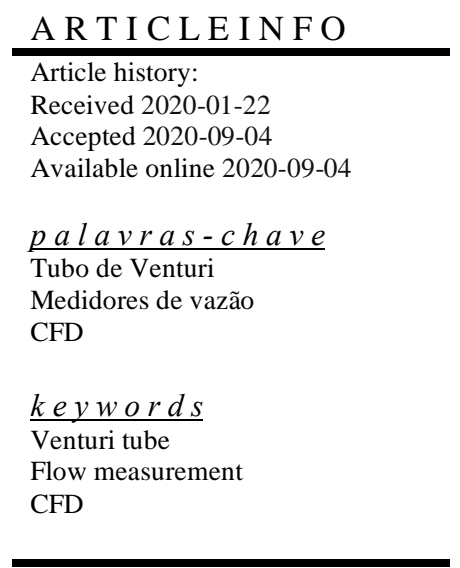

\begin{abstract}
A B S T R A C T
The Venturi tube measures the fluid's flowrate by use of an obstruction in the flow path. As a tool to understand the fundamental principles of Chemical Engineering, an experimental device for flow measurement integrating a Venturi tube was developed in the course of the Chemical Engineering Projects I from the Federal University of Lavras. The system was constructed with materials of low-cost and easy access. The experimental results for the flow and pressure drop were compared with theoretical values and with additional data obtained by the use of a numerical and computational method (CFD). The discharge coefficient was $0,683 \pm 0.018$ [-], an intermediate value of those found in the literature for orifice plate and flow nozzle meters. The numerical method was successfully able to predict the pressure drop in the system.
\end{abstract}

\section{R E S U M O}

O tubo de Venturi é um medidor de vazão de gases e líquidos por obstrução. Como ferramenta para a consolidação de conceitos fundamentais da Engenharia Química, um aparato experimental para medição de vazão utilizando um tubo de Venturi foi desenvolvido ao longo das aulas da disciplina Projetos em Engenharia Química I, da Universidade Federal de Lavras. O sistema foi construído com materiais de fácil acesso e baixo custo. Os resultados experimentais de vazão e variação de pressão foram comparados com valores teóricos e com dados obtidos pela aplicação de um método numérico computacional (CFD). O cálculo do coeficiente de descarga resultou em um valor de 0,683 \pm 0,018 [-], valor intermediário entre os encontrados na literatura para medidores de vazão do tipo placa de orifício e bocal. $O$ modelo numérico utilizado foi capaz de prever de forma satisfatória a perda de carga no sistema. 


\section{N O M E N C L A T U R E}

$\mathrm{A}_{t} \ddot{I}$ Area at Vena Contracta

$\mathrm{C}_{\mathrm{d}}$ Ï Discharge coefficient

$\left[\mathrm{cm}^{2}\right]$

D Ï Tube Diameter

$D_{1} I$ Characteristic lenght of the flow

$\mathrm{D}_{2} \ddot{\mathrm{i}}$ Characteristic length of the flow

$D_{t}$ Ï Choke section Diameter

$D_{v}$ ï Vena Contracta Diameter

g ï Gravitational acceleration

$\hat{E}_{\text {true }}$ Ï True Mass Flow

$\hat{E}_{\text {theoretical }} \mathbf{I}$ Theoretical Mass Flow

Qï Flow

Qtrue $\mathrm{I}$ True or Experimental Flow

Qtheoretical $I$ Theoretical Flow

Re ï Reynolds number

qo ï Height difference

qp ï Pressure drop

qPexperimental Ï Experimental Pressure Drop

$q \mathbf{P}_{\text {simulation }}$ ï Simulated Pressure Drop

f $̈$ Fluid density

\section{INTRODUCTION}

Fluid mechanics offers many applications for the flow measurement of fluids in the industrial environment, being used, for example, for the flow measurement of different fluids in pipes in the food, chemical and petroleum industry. The flowmeters vary in size, cost, precision, sophistication, capacity, versatility and operational principles (Cimbala, 2015).

The obstruction-type flow meters, largely used for the flow measurement of gases and liquids, can be classified as orifice plate, flow nozzle and venturi tube. The orifice plate consists of a perforated plate, which is installed perpendicularly to the piping axis. The orifice plate is economic and easy to install, change and manage. However, it leads to high pressure drops in the pipe.

The flow nozzle flowmeters have applications in the flow measurement of steam and corrosive or abrasive fluids. Differently from the orifice plate, it has an intermediary cost, as well as a moderate pressure drop in the pipe, but can support high velocities and temperatures.

The Venturi tube is a simple unit, formed by a choking section between two conical sections. Its function is to change the velocity of the fluid, and therefore, cause a pressure drop that can be measured through pressure gauges (manometers, for example). Thus, the flow value can be inferred using the Bernoulli and continuity equations. The Venturi flowmeters are highlighted for their low pressure drops and high precision. They are usually cast and machined with low tolerances for the standard design, and therefore are bulky and expensive.

With the intent of consolidating the fundamental concepts of Chemical Engineering, a simple experimental unit was designed for flow measurement utilizing a Venturi Tube. The flowmeter was developed during the Chemical Engineering Projects I subject from the Chemical Engineering course at the Federal University of Lavras (UFLA). As a way to complement the experimental results, a mathematical model was established and applied to the finite volume method to simulate the system using Computational Fluid Dynamics (CFD).

CFD uses the finite volume method to discretize the geometrical domain so that the numerical methods can be applied, and an approximate result is obtained. The result is calculated through the Navier-Stokes equations, and the numerical method is necessary as the equations for laminar flows $(\operatorname{Re}<2300)$ are only solved algebraically.

The application of a numeric method can be segmented into three steps: preprocessing, processing, and postprocessing. In the preprocessing, the geometric domain is defined, as well as its discretization, which has the mesh as a result. The most utilized software to create the geometry are SpaceClaim $^{\circledR}$, DesignModeler $^{\circledR}$, Gambit $^{\circledR}$, SolidWorks $^{\circledR}$, etc. As for the meshing of the geometry, commonly used software are ICEM ${ }^{\circledR}$, Meshing $^{\circledR}$ and Gambit ${ }^{\circledR}$. In this step the physical properties of the fluid, as well as other parameters (initial and boundary conditions) needed for the solving can be defined (Lima, 2005).

In the processing phase, a solver, based on the numerical model, is used to obtain the relevant variables (velocity, pressure, temperature). The commercial software that are most commonly used in the processing phase are FLUENT $^{\circledR}$ and $\mathrm{CFX}^{\circledR}$, both pertaining to the computational package ANSYS. The results are then analyzed in the postprocessing phase, in order to verify the validity of the numerical method through comparisons with the experimental data (Lima, 2005).

Direct Numerical Simulation (DNS) is a modeling technique that consists in solving the complete Navier-Stokes equations for all the mesh points, as well as the time and spatial scales of the movement. In turbulent flows, the vortices take up a large range of length and time, and it is always tridimensional. Furthermore, it is necessary a great number of cells in a tridimensional mesh, that is, a great refinement of the mesh in order to accurately represent the system, which demands a great computational cost.

A distinctive trait of turbulent flow is its high degree of freedom, which corresponds to the number of linear equations to be solved for all the cells of the mesh, so that the flow can be accurately simulated. In order to simulate the small-scale vortices of turbulence in a tridimensional flow, it is necessary to reduce the scale of an equipment in $\mathrm{Re}^{9 / 4}$. This type of simulation requires a low number of models, yet the computational cost is still high considering the high number of cells necessary.

The turbulence is one of the most essential characteristics of CFD, and is a trait given to any dynamic system with a high enough degree of freedom. The turbulence occurs in various practical engineering operations of great relevance, and it is defined by a high Reynolds number (Vieira, 2006). 
Typically, the use of DNS modelling is not viable, and therefore, a less refined mesh is commonly used. However, by reducing the number of cells of a mesh, the small-scale vortices of turbulence cannot be properly simulated and its information is lost. To remedy this, the turbulent models are introduced so as to simulate the turbulence with a low computational cost. The modelling becomes more complex, as each model has their own ideal conditions for its application. These types of turbulent modelling are called RANS, and encompass the following models: $\mathrm{k}-\subsetneq \mathrm{k}-\gamma$ and RMS. The LES model utilizes both DNS and RANS modelling characteristics, and the DES model combines the LES and RANS models.

To better comprehend the concepts behind the flow measurement in internal flows, this paper had the objective to construct and operate an experimental apparatus for flow measurement using a óVenturi tubeô The apparatus was constructed using easy-access and low-cost materials in order to increase its accessibility. The experimental flow value was obtained directly and it was compared with the theoretical flow value. The pressure before and after the choke section was also measured and the obtained numerical results were compared to the experimental results.

\section{MATERIALS AND METHODS}

\subsection{Materials}

The experimental apparatus built using a Venturi tube is shown in Figure 1. For the assembly of the equipment, low-cost materials were used, easily acquired on the local Lavras, MG market. These materials were as follows: $30 \mathrm{~L}$ dustbin used as water reservoir (a), $25 \mathrm{~mm}$ ball valve (b), $25 \mathrm{~mm}$ tube (c), 20 $\mathrm{mm}$ tube (d), hose pipe reducer $25 \times 20 \mathrm{~mm}$ (e) and silicone hoses (f), as well as other materials such as adhesives, thread sealing tape, rulers and clamps used for the manometer construction. The total cost was of $\mathrm{R} \$ 71.59$.

\subsection{Experimental Methodology}

For the assembly of the apparatus shown in Figure 1, a tube $\left(\mathrm{D}_{1}=25 \mathrm{~mm}\right)$ with $0.10 \mathrm{~m}$ in length was fixated into an orifice drilled in the dustbin, and the ball valve was fixated to the tube. A section of the $25 \mathrm{~mm}$ tube with $0.45 \mathrm{~m}$ in length was connected to the valve, followed by the hose pipe reducer and a $0.30 \mathrm{~m}$ in length section of the smaller tube $\left(\mathrm{D}_{2}=20 \mathrm{~mm}\right)$. A second hose pipe reducer was connected to the smaller tube, and lastly, a $0.15 \mathrm{~m}$ in length section of the larger tube, completing the structure of the Venturi tube.

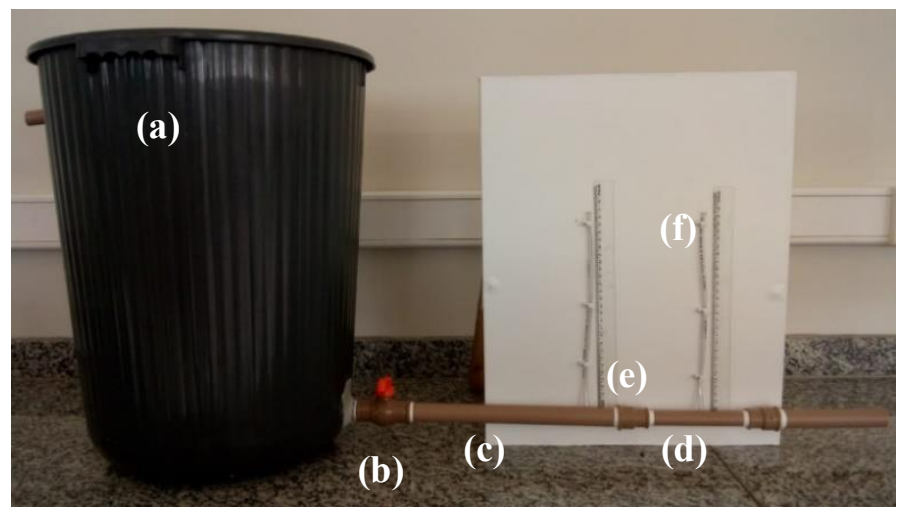

Figure 1 - Experimental apparatus for flow measurement.
The experimental flow measures $\left(Q_{\text {true }}\right)$ were made directly (six replicas) with the measure of the volume drained from the system in a determined time interval. The theoretical volumetric flow $\left(\mathrm{Q}_{\text {theoretical }}\right)$ was calculated through Equation 1, obtained by the continuity and Bernoulli equations considering steady-state, incompressible fluid, flow along one streamline, frictionless flow, uniform velocities and negligible height difference.

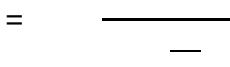

in which, $\mathbf{q P}$ is the pressure drop by the flow through the Venturi meter $[\mathrm{Pa}], \mathrm{D}_{1}$ e $\mathrm{D}_{2}$ are the characteristic lengths for internal flow [cm], as shown in Figure 2 for a flow through a generic nozzle.

The pressure drop is calculated through the difference between the fluid height in the silicon hoses (qp) using Equation 2.

$\Delta=\Delta$ ?

in which, $f$ is the fluid density $\left[\mathrm{g} / \mathrm{cm}^{3}\right]$ and $\mathrm{g}$ is the gravitational acceleration $\left[\mathrm{cm} / \mathrm{s}^{2}\right]$.

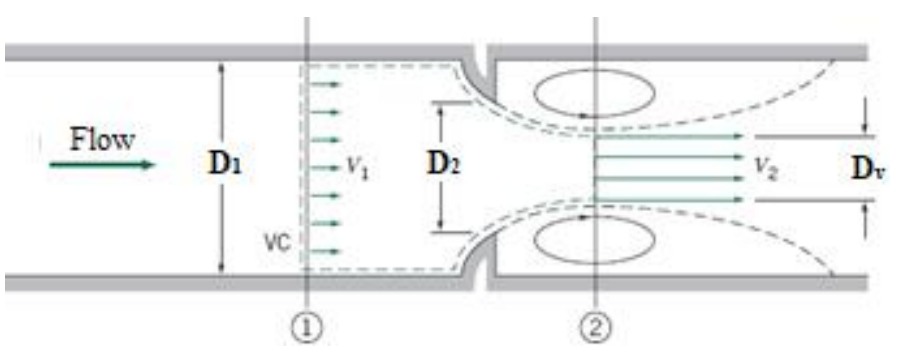

Figure 2 - Internal flow through a generic nozzle (Fox et al., 2018).

The theoretical mass flow $\left(\hat{\mathrm{E}}_{\text {theoretical }}\right)[\mathrm{L} / \mathrm{s}]$ is calculated through Equation 3, based on the values of $æ, D_{1}$ e $D_{2}$. The discharge coefficient $\left(\mathrm{C}_{\mathrm{d}}\right)[-]$ is used due to the unfeasibility of obtaining the diameter at the second section $\left(\mathrm{D}_{2}\right)$. Therefore, the discharge coefficient is necessary in order to correct the true mass flow $\left(\hat{\mathrm{E}}_{\text {true }}\right)[\mathrm{L} / \mathrm{s}]$ calculation with the choke section diameter $\left(D_{t}\right)$. The $C_{d}$.is determined by Equation 4 .

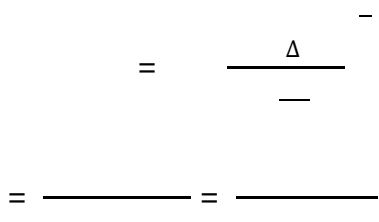

Values for the discharge coefficient are found in the literature at specific ranges of Reynolds (Fox et al., 2018):

Orifice plate $\ddot{\mathrm{i}} \mathrm{Re}>30,000 \ddot{\mathrm{i}} \mathrm{C}_{\mathrm{d}} \cong 0.61$

Flow nozzle ï $\mathrm{Re}>3000$ ï $\mathrm{C}_{\mathrm{d}} \cong 0.96$

Venturi tube ï $\operatorname{Re}>200,000 \ddot{~} 0.98<\mathrm{C}_{\mathrm{d}}<0.995$ 
With the values for the theoretical and true discharge coefficients, it is possible to calculate the relative error of the experiment using Equation 5.

$$
(\%)=\frac{1}{1} 100
$$

Figure 3 illustrates a comparison between the Venturi tube and orifice plate geometries as to better identify how the structure of the equipment can influence the fluid flow.

(a)
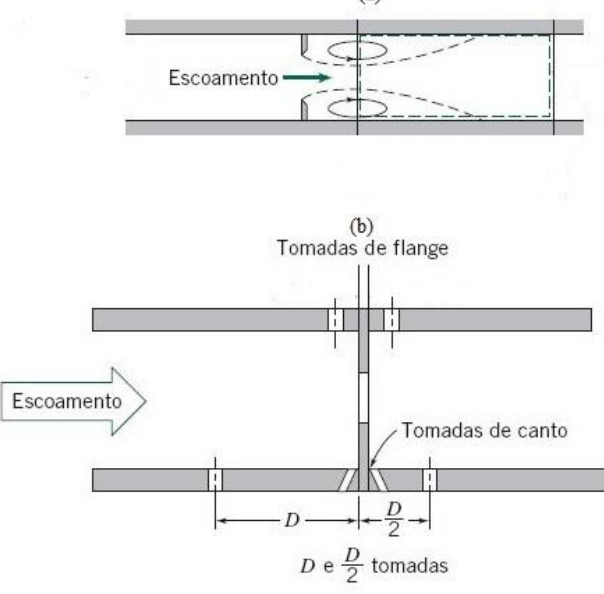

Figure 3 - Geometry comparison between Venturi tube (a) and orifice plate (b). Adapted from (FOX, 2018).

\subsection{Numeric Solution}

The numeric solution domain is divided into small control volumes so that the transport equations can be applied (Vieira, 2006). The geometry and mesh construction were made through the commercial software GAMBIT $^{\circledR}$. For the simulations, the constructed mesh is used by the software FLUENT 19.0, pertaining to the computational package ANSYS. The academic version was used.

The tridimensional mesh for the Venturi tube was constructed in the software GAMBIT ${ }^{\circledR}$. In order to guarantee a stable simulation, the elements of a mesh need to be preferentially hexahedral, as it is a regular shape that facilitates the convergence of the numerical calculations. For cylindrical geometries, however, the construction of an exclusively hexahedral and regular mesh is not possible.

In order to maintain mesh quality in cylinders, it is possible to construct a concentric smaller cylinder, that will be treated by the simulation as an interior volume. Through this, a hexahedral mesh can be constructed in the volume between the two cylinders with the help of two perpendicular planes positioned longitudinally to the equipment. For the volume inside the smaller cylinder, a tetrahedral mesh was used.

Before transferring the mesh from GAMBIT $^{\circledR}$ to FLUENT $^{\circledR}$, a boundary-type was assigned to each face of the geometry, so that, prospectively, these faces would be able to receive the appropriate boundary conditions necessary for the simulation. The software GAMBIT ${ }^{\circledR}$ has its own nomenclature depending on the nature of the face. For the Venturi tube, the walls were defined as ñwallò, the fluid inlet was defined as ñvelocity-inletò, the fluid output as ñpressure-outletò, and the internal faces created to facilitate the creation of the mesh were defined as ñinteriorò. Figure 4 illustrates the geometry of the equipment, referring to its dimensions and the created mesh, containing 510,000 cells.

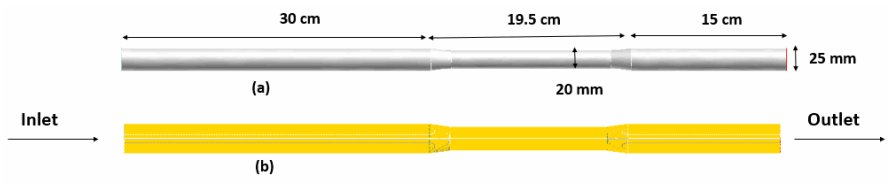

Figure 4 - (a) Geometry and dimensions, and (b) computational mesh built with the software GAMBIT ${ }^{\circledR}$.

The boundary conditions configured into the software FLUENT $^{\circledR}$ are listed in Table 1.

Table 1 - Conditions and models used in the software FLUENT $^{\circledR}$.

\begin{tabular}{|c|c|}
\hline \multicolumn{2}{|c|}{ 3D simulation } \\
\hline \multicolumn{2}{|l|}{ Transient state } \\
\hline \multicolumn{2}{|c|}{ Outlet: Atmospheric pressure: $(100,700 \mathrm{~Pa})$} \\
\hline \multicolumn{2}{|l|}{ Feeding flow: $537.31 \mathrm{~cm}^{3} / \mathrm{s}$} \\
\hline \multirow{3}{*}{\multicolumn{2}{|c|}{$\begin{array}{l}\text { Turbulence model: Large Eddy Simulation (LES) } \\
\text { Momentum discretization method: QUICK } \\
\text { Pressure discretization method: PRESTO! }\end{array}$}} \\
\hline & \\
\hline & \\
\hline \multirow{4}{*}{$\begin{array}{l}\text { Relaxation factors (Petri et al., } \\
\text { 2009) }\end{array}$} & Pressure: 0.3 \\
\hline & Density: 0.1 \\
\hline & Body Force: 1 \\
\hline & Momentum: 0.1 \\
\hline \multicolumn{2}{|l|}{ Convergence criteria: $10^{-4}$} \\
\hline
\end{tabular}

\section{RESULTS AND DISCUSSIONS}

At first, it is important to highlight that the apparatus was adequate to obtain the experimental data ( $Q$ and $q$ h). The average value obtained for the experimental flow was of $(0.537$ $\pm 0.014) \mathrm{L} / \mathrm{s}$. The low standard deviation suggests a good reproducibility of the utilized experimental procedure.

The pressure drop for the fluid (qP) over its flow along the equipment was obtained through the height difference of the water ( $q$ ) in vertically supported silicon hoses (see Figure 1), by the use of Equation 2. The measured op and the calculated pressure drops are presented together with their average value and standard deviation in Table 2. An analysis of the data obtained showed low standard deviations for the height difference, indicating good reproducibility for the measurement.

With the experimental values of the flow, height difference and pressure drop for the fluid, the theoretical flow was obtained as well as the discharge coefficient by Equations 3 and 4, respectively. The results are shown in Table 2. 
Table 2 - Measured values for the height difference and pressure drop.

\begin{tabular}{|ccc|} 
Measurement & $\Delta \mathbf{h} \mathbf{( c m )}$ & $\Delta \mathbf{P}(\mathbf{P a})$ \\
\hline 1 & 0.185 & 1811.583 \\
2 & 0.187 & 1831.168 \\
3 & 0.189 & 1850.753 \\
4 & 0.188 & 1840.960 \\
5 & 0.191 & 1870.337 \\
6 & 0.192 & 1880.130 \\
Average value & $\mathbf{0 . 1 8 9} \pm \mathbf{0 . 0 0 2}$ & $\mathbf{1 8 4 7 . 4 9} \pm \mathbf{2 3 . 0 8}$
\end{tabular}

As it is possible to note, the obtained value for $C_{d}$ was intermediate to those found in the literature for orifice plate flowmeters $(=0.61)$ and flow nozzle flowmeters (å 0.98). This result can be explained by the reductions used for the apparatus construction, which were abrupter than those found in traditional Venturi tubes and flow nozzle flowmeters, and subtler than those found in orifice plate flowmeters, as illustrated in Figure 3.

Furthermore, an analysis of the results shows an expressive difference between the experimental flow and theoretical flow. This difference can be attributed to the geometrical shape of the meter. Subtle reductions in flowmeters show smaller variations between theoretical and experimental flow, which reflects in discharge coefficients of the approximate value of one (Fox et al., 2018). Therefore, the difference obtained can be justified by the obtained $\mathrm{C}_{\mathrm{d}}(=0.683)$ with a value inferior to 1.0. Additionally, the difference can be attributed to the uncertainty of the experimental measurements, for example, in the drained water volume and the value of the manometer.

Table 3 - Calculated values for theoretical flow and discharge coefficient $\left(C_{d}\right)$.

\begin{tabular}{|ccccc|} 
Measurement & $\begin{array}{c}\Delta \mathbf{P} \\
(\mathbf{P a})\end{array}$ & $\begin{array}{c}\mathbf{Q}_{\text {true }} \\
(\mathbf{L} / \mathbf{s})\end{array}$ & $\begin{array}{c}\mathbf{Q}_{\text {theoretical }} \\
(\mathbf{L} / \mathbf{s})\end{array}$ & $\mathbf{C}_{\mathbf{d}}$ \\
\hline 1 & 1811.58 & 0.538 & 0.779 & 0.691 \\
2 & 1831.17 & 0.529 & 0.783 & 0.676 \\
3 & 1850.75 & 0.522 & 0.787 & 0.663 \\
4 & 1840.96 & 0.539 & 0.785 & 0.686 \\
5 & 1870.34 & 0.567 & 0.791 & 0.717 \\
6 & 1880.13 & 0.530 & 0.794 & 0.668 \\
& $\mathbf{1 8 4 7 . 4 9}$ & $\mathbf{0 . 5 3 7} \pm$ & $\mathbf{0 . 7 8 7} \pm$ & $\mathbf{0 . 6 8 3} \pm$ \\
Average value & $\pm \mathbf{2 3 . 0 8}$ & $\mathbf{0 . 0 1 4}$ & $\mathbf{0 . 0 0 5}$ & $\mathbf{0 . 0 1 8}$ \\
& & & &
\end{tabular}

For the simulation in the software FLUENT $^{\circledR}$, the geometry and mesh were made with the software GAMBIT ${ }^{\circledR}$. The utilized mesh had 510,000 cells. The simulated time was defined as approximately five times the residence time for the water flowing inside the system. Two planes were defined in FLUENT $^{\circledR}$ coinciding with the manometer connections in order to measure the simulated pressure drop for the Venturi tube.
The simulated and experimental pressure drop as a function of the time for 1.5 seconds of flow can be observed in Figure 5.

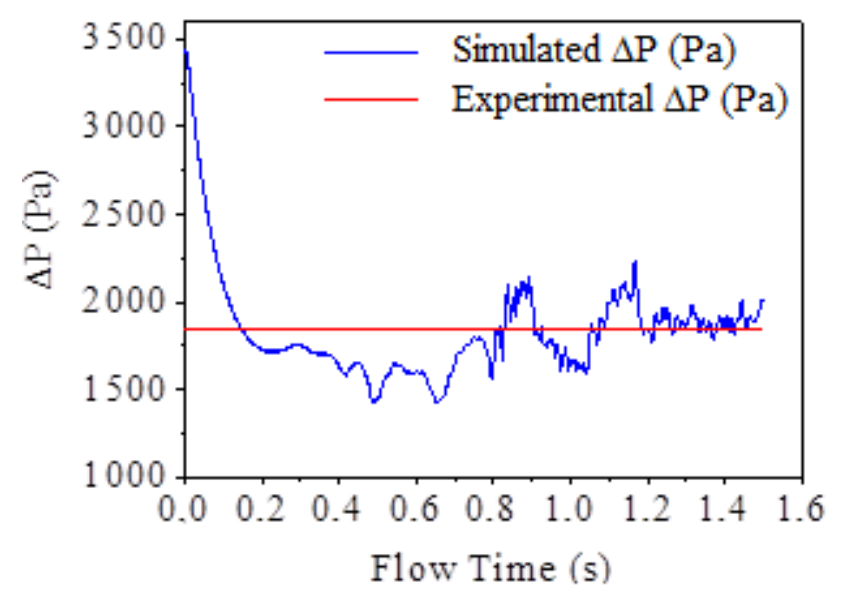

Figure 5 - Simulated and experimental pressure drop as a function of the time.

Analyzing the results shown in Figure 5, it is possible to note that initially the pressure drop value fluctuated considerably due to the numerical instability at the start of the simulation. After approximately 1.2 seconds, however, its value stabilizes and fluctuates moderately around a single value.

The average value for the simulated pressure drop after its stabilization in 1.2 seconds, as well as the previously obtained experimental pressure drop can be seen in Table 4, with their respective standard deviation. The standard deviation for the simulation was considerably higher than the one for the experimentally obtained pressure drop value. That can be explained by the simulated time. A higher simulation time would make the numerical calculation go through more iterations, which could provide a more consistent and stable result.

Table 4 - Average value for the simulated and experimental pressure drop.

\begin{tabular}{ccc|} 
& $\Delta \mathbf{P}$ simulation & $\Delta \mathbf{P}$ experimental \\
$(\mathbf{P a})$ & $(\mathbf{P a})$ \\
\hline Average value & 1886.72 & 1847.50 \\
Standard deviation & 50.23 & 23.08
\end{tabular}

With CFD it is also possible to analyze the flow profiles for the fluid inside the Venturi tube. Figure 6 illustrates the profiles for the dynamic pressure $(\mathrm{Pa})$, total pressure $(\mathrm{Pa})$ and fluid velocity $(\mathrm{m} / \mathrm{s})$ along the equipment, captioned through colors to represent the intensity of the variable. 


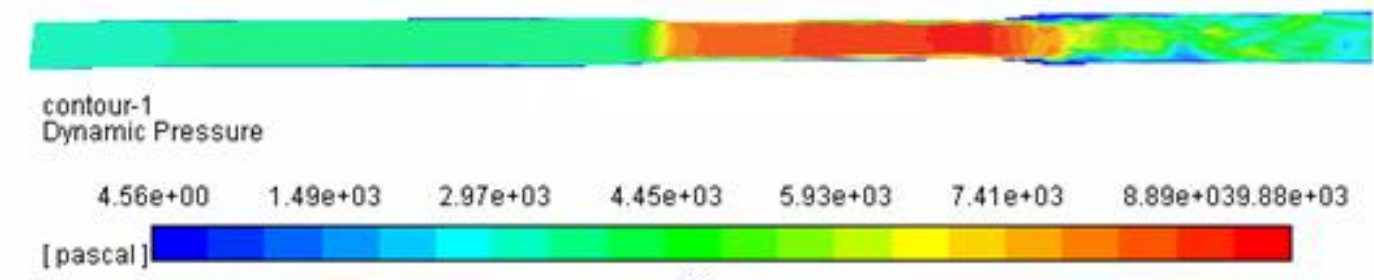

(a)

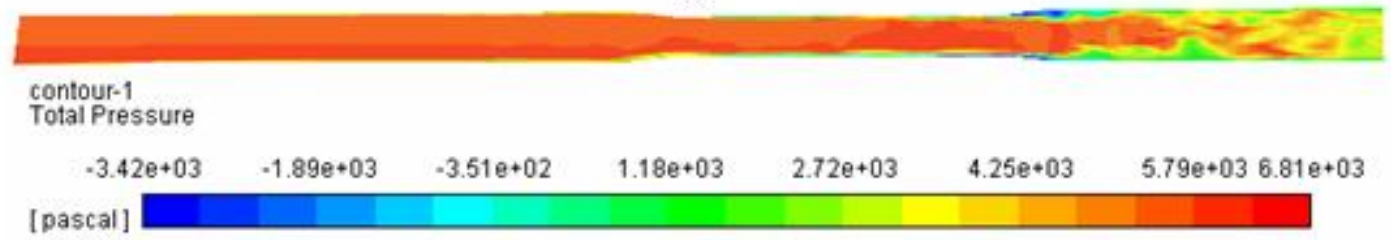

(b)

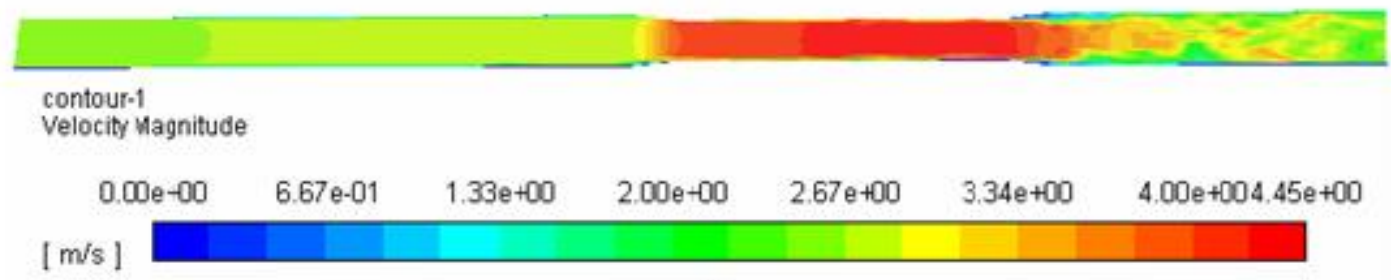

(c)

Figure 6 - Dynamic pressure (a), total pressure (b) and velocity (c) profile inside the Venturi tube.

In the dynamic pressure profiles (Figure 6a) there is a rise in the pressure at the choke section. This increase is coherent to the physical properties of the fluid, since the dynamic pressure is dependent and directly proportional to the velocity.

The results for the dynamic pressure are reiterated by the velocity profile (Figure 6c), in which the velocity is higher at the choke section, as expected for the flow area reduction. The velocity profiles also provided information of the flow type, which was laminar at the start of the equipment and started showing turbulence traits after the choking section. This behavior might be due to the flow area expansion combined with the choke section conserved inertia.

In the total pressure profiles (Figure 6b), the pressure value is reduced as the fluid traverses the tube. This behavior represents the pressure drop caused by the reductions, as well as the straight sections of the tube.

As demonstrated by Figures 5 and 6, the numeric results obtained were considerably converging to those experimentally obtained. This not only validates the numeric methodology, but also complements the reliability of the experimental values. Thus, the numerical solution provided a complementary validation between the numerical and experimental studies.

The convergence of the results is provided by the utilized models that were sufficient to achieve the convergence of the system. The mesh was also important, as it contained a sufficient number of cells to properly represent the system.

To utilize and reproduce this didactic equipment and guarantee its functions, the CFD tool is a good alternative for the validation of the system. Since the reproducibility of the flow inside the tube cannot be guaranteed as it depends on the fluid reservoir, a numeric model can be utilized in order to validate the reproduced equipment. For that, it is recommended the reproduction of the numerical model studied in this paper, constituting of the same configurations, initial and boundary conditions. Consequently, the obtained pressure drop values can be compared to the numerical and experimental values here obtained.

With the validation of the new numerical method, it is possible to use the new experimental flow of the reproduced equipment in a new simulation. Then, the experimental methodology can be properly validated by the simulation configured with the new experimental flow. Additional tests can be made with similar meshes containing lower cell numbers, so as to lower the computational cost and make the CFD use more accessible. The results obtained by the use of a smaller number of cells can be once more compared to the experimental values here obtained to validate the new numerical model.

\section{CONCLUSION}

The apparatus construction for the study of a fluid flow using a Venturi tube flowmeter was adequate to the proposed study. The data was successfully obtained and helped with the comprehension of the theoretical concepts previously acquired in the Chemical Engineering course. The experimental values for the flow $(0.537 \pm 0.014) \mathrm{L} / \mathrm{s}$, were compared to the theoretical values $(0.787 \pm 0.005) \mathrm{L} / \mathrm{s}$ and were considered to be reproducible. The also reproducible op values were measured and used for the pressure drop calculation for the experimental apparatus.

The experimental study allowed for the determination of the $C_{d}$ values, with a $43.48 \%$ variation in comparison to the 
value found in literature $\left(\mathrm{C}_{\mathrm{d}}=0.98\right)$ as calculated through Equation 5. The high error value is coherent considering the geometrical differences between the constructed apparatus and the commercial Venturi Tube, with a considerably more abrupt diameter reduction for the former. This, however, did not compromise the flow measurement, as the calculated $\mathrm{Cd}$ value was used to correct the experimental values.

The experimental values of $q \mathrm{p}$ were convergent to the simulated values. This result suggests that, while the materials used for the apparatus construction influence the results (as an abrupt reduction for the choke section, differently from what occurs in most commercial Venturi tubes), the flow properties throughout the Venturi tube were adequately reproduced through the use of the discharge coefficient.

Comparing the experimental values to the theoretical values and the simulation results, it was possible to identify pressure differences inside the Venturi tube, highlighting its functioning principle and correlating the obtained data.

\section{ACKNOWLEDGEMENTS}

The authors thank the support of the Engineering Department of Federal University of Lavras for the endorsements given for the formulation of this project.

R E F E R E N C E S

CIMBALA, Y. A. Mecânica dos fluidos ï Fundamentos e Aplicações. $3^{\text {a }}$ ed., Mc Graw Hill/Bookman, 2015.

FOX, R. W.; MCDONALD, A. T.; PRITCHARD, P. J.; MITCHELL, J. Introdução à mecânica dos fluidos. 9a ed., Rio de Janeiro: LTC, 2018.

LIMA, R. C. Simulação de grandes escalas de escoamentos incompressíveis com transferência de calor e massa por um método de elementos finitos e subdomínios. 2005. X p. Dissertação ï Faculdade de Engenharia de Ilha Solteira, São Paulo, SP, 2005.

PETRI, I. J.; DUARTE, C. R.; VIEIRA, L. G. M. Aplicação das técnicas de CFD para a predição da distribuição de vazões volumétricas em hidrociclones dispostos em distintas baterias, 2009, Anais do Congresso Brasileiro de Sistemas Particulados. Campinas, 2009.
VIEIRA, L. G. M. Otimização dos processos de separação de hidrociclones filtrantes. 2006. 122 f. Tese (Doutorado) Universidade Federal de Uberlândia, Uberlândia, MG, 2006 